\title{
FACTORS AFFECTING THE ADOPTION OF MOBILE BANKING: THE CASE OF UNITED BANK ADDIS ABABA CITY CUSTOMERS
}

\author{
Serkalem Dandena ${ }^{1}$, Mekuanint Abera Timbula ${ }^{2}$, Tadele Mengesha ${ }^{3}$ \\ ${ }^{1,2,3}$ Department of Banking and Finance, Jimma University, Ethiopia \\ serkaledan@yahoo.com, meki2031@gmail.com, tdlmngsh@gmail.com
}

\section{Original Scientific Paper doi:10.5937/jouproman8-24520}

\begin{abstract}
Tele Communication Technology now a day has an important impact on a day to day activity of human being in all over the world. One of the bequests drawn from Tele communication technology is Mobile Banking system. The aim of this study was to examine factors that affecting the adoption of mobile banking in Ethiopian Banking industry. The collected data was analyzed using descriptive statistics, correlation and regression analysis. Results are presented using tables, figures, graphs and charts to show the extent of influence of identified factors on the adoption of mobile banking. The data analysis includes a correlation matrix to test the direction and strength of the study variables against m-banking adoption and regression analysis to examine the extent to which they bring to adoption of m-banking. The major finding of the study reveals, Technological and Organizational factors from the institutional perspective and customers' experience and voluntariness of use from customers' perspective had strong and positive relation with adoption of $\mathrm{m}$-banking. However, gender and age from the customers view and Environmental factor from the institutions view had a negative relationship with mobile banking adoption. The study indicated that Technology and customer's voluntariness of use had an impact on the adoption of m-banking in greater extent. Therefore, the result recommended that to enhance the m-banking adoption to the required level, United Bank and other banks should invest and deploy on new and "state of the art" technologies with the required human capital and develop a clear strategy to work exhaustively towards the belief of customers to use m-banking system.
\end{abstract}

Key words: M-Banking, Adoption, United Bank, TOE

\section{Background of the Study}

Today's globalized and dynamic business environment forces many businesses to face increased intensive competition. The competitive business environment and rapid technological change is the key to sustainable competitive advantage in delivering high quality services that will in turn result in satisfied customers. High quality service as indicated by rapid technological development is a major differentiation variable and source of competitive advantage (Boshoff, 2009)Among the various service sectors, the rapid growth and changes in information technology have transformed the world of financial institutions like banks. Financial institutions plays an important role in providing different financial services such as mobilizing financial resources from the surplus units to those who need financial resources to undertake different economic activities. Traditionally banks are the major players in the financial sectors in mobilizing public money in terms of saving and lend it to those who need it. This is the reality in developing countries even today where alternative financial institutions are at lower level of development relative to the banks. 
"These days, the function of commercial banks is confined not only to advancing loans to the public and accepting their deposits, their contribution in accelerating the rate of economic development in under- developed and developing countries is very important” V. K. Gangal(2013)

Access to banking service will improve the qualities of lives of a society; however, access to banking service in developing countries is at lower level. Among the various factors which contribute to this poor development are: deficient infrastructure, physical geographical isolation or inaccessibility, financial illiteracy, all of which culminate into exceedingly high cost of providing banking services.

The challenges we have seen previously in providing access to banking services in Sub-Saharan Africa in general and Ethiopia in particular can be addressed by using mobile phone and mobile banking technology as witnessed empirically in the neighboring country Kenya. Hence, mobile banking is an opportunity for the banks in Ethiopia to address the potential market in the country where access to banking services is very low.

Though several studies have contributed substantially to the literature on m-banking adoption by various scholars in countries such as Brazil (Laukkanen et al 2010), China (Wang et al. 2010) and Taiwan (Luarn and Lin 2005), the finding may not be applicable to countries like Ethiopia due to cultural, economic and legal environments. Moreover the existing research did not analyze the contribution of demographic factors such as gender, age, experience and voluntariness of use towards the adoption of m-banking.
Therefore this study is intended to fill the literature gap in the local context as well as knowledge gap by providing better understanding on the crucial demographic factors and major institutional factors contributing in the adoption of m-banking among decision makers of the banking industry so that effective management of those factors hindering the success of $\mathrm{m}$ banking service can take place.

\section{Research Design}

The study design of this research is descriptive and explanatory. Descriptive research design is applied to describe the key factors that affect the adoption of mbanking in United Bank and explanatory research aims to provide explanation regarding the casual relationship between Adoption of m-banking which is dependent variable of the research and different factors stated on the conceptual framework as an independent variables. Quantitative research approach also be applied in this research work so as to address the research objective and to test the research hypothesis.

\section{DATA ANALYIS RESULTS AND DISCUSSIONS}

In order to find out environmental factors affects adoption of M-Banking, the following summary of respondents is discussed as follows. Regarding their agreement on Strong legal and regulatory framework by the government enforce banking industries, majority of respondents $44.8 \%$ agreed that, there is Strong legal and regulatory framework by the government enforce banking industries. The researcher also directly posed a question regarding the Government support enables smoother mbanking adoption. 
Based on this the Majority $44.8 \%$ of respondents agreed that there exists Government support enables smoother mbanking adoption. With regard to the Strong vision of the future M-banking, indicated that the majority of respondents $34.7 \%$ were disagreed to the statement, that means "it is so difficult to predict Strong vision of the future M-banking. This indicates that, there exists a challenge in terms of awareness about the strategic plan of the bank in regarding to these issues. Thus the concerned stakeholders are recommended to devise a strategic plan and awareness that is clear and understood vision of the future M-banking.

$48.2 \%$ agreed that there is Competitive pressure drives m-banking investment. Moreover, most of $(42.1 \%$ ) respondents responded that there is Improvement of ICT infrastructure that links different banks. From the other environmental factors also, that is there is tight foreign currency regulation, majority $(55.2 \%)$ agreed that there is Tight foreign currency regulation. Moreover, majority (37.9\%) agreed that, there is Prediction of more customer acceptance of m-banking With regard to the Availability of hardware in country (POS, ATM, server), indicated that the majority of respondents $58.4 \%$ were disagreed to the statement, that means it is so difficult to have nearby and easily accessibility/availability of hardware in country (POS, ATM, server) . This indicates that, there exists a challenge in terms of having nearby and easily accessibility/availability of hardware in country (POS, ATM, and server). Thus the concerned bank managers/ stakeholders are recommended to devise a strategic direction in allocating resources for nearby and easily accessibility/availability of hardware in country (POS, ATM, and server).
With regard to "M-banking lowers operating cost by increasing productivity and profitability of the bank, " majority of respondents $51.7 \%$ were agreed the statement. As seen from the above table, majority $41.3 \%$ also agreed that their bank has Strong organizational culture of new technological innovation and staff training. Most of respondents $51.7 \%$ also agreed that their bank has a strong belief in better branding and better responsiveness to the market. Moreover, most of respondents, $48.2 \%$ responded that M-banking Improves customer service and hence increase customer satisfaction. From the above technological factors also, most of respondents $37.9 \%$ disagree that $\mathrm{M}$ banking increases efficiency by reducing error. That means majority of respondents still uses manual operation apart from digital banking system so as to reduce error With regard to M-banking Lowers security issues and boosts user's confidence. Majority (41.3\%) agreed that M-banking Lowers security issues and boost user's confidence. Moreover, majority (68.9\%) agreed that, Provides up to date and sufficient information. Majority (62\%) of respondents disagreed that, "M-banking Provides easy and user friendly system. This shows that, though $31.1 \%$ agreed that M-banking Provides easy and user friendly system but still because of poor network infrastructure and internet access M-banking is not providing user friendly system to the expected level, thus the concerned stakeholders are advised to address the gap and solve the poor network infrastructure and internet access problem so that M-banking will be providing user friendly system. 
With regard to the statement that, Minimizes inconvenience by providing 24/7 banking services, majority $44.8 \%$ don't have clear opinion or neutral about the statement. Regarding their opinion about Mbanking delivers greater output with the help of advanced technology $34.5 \%$ don't have clear opinion or neutral about the statement.

Majority (51.7\%) of respondents agreed that, there should be improved access to computer/internet/cell phone to perform m-banking.

Regarding to Demographic factors (gender), that they have enough information about Mobile-Banking service, "the majority of respondents $41.3 \%$ were disagreed the statement. Which means majority of respondents do not have enough information about Mobile-Banking service. Thus the bank is advised to arrange an intensive awareness program in delivering enough information about Mobile-Banking service. Majority of respondent $41.4 \%$, also agreed that they have a good skill in using smart phone .Most of respondents $44.8 \%$ also agreed that they have positive beliefs towards adopting m-banking. Moreover, most of respondents, $44.8 \%$ responded that they have positive attitude towards adopting $\mathrm{m}$-banking. From the above demographic (gender) factors also, most of respondents $31 \%$ are neutral about the statement that they have greater interest in using IT related application.

Regarding to Demographic factors (age) that they can adopt new technological innovations very fast, majority (41.4\%), agreed that they can adopt new technological innovations very fast. Moreover, on the statement "It is very simple for them to handle or operate $\mathrm{m}$ banking“, majority of respondents $62.1 \%$ agreed that it is very simple for them to handle or operate m-banking. Regarding, they are ready to face any financial risk while they are using m-banking service, majority (51.7 \%)agreed they are ready to face any financial risk while they are using m-banking service. With regard they have a good skill in using computer, $48.6 \%$ respondents, disagreed they have a good skill in using computer.

In order to find out demographic factors (experience) affects adoption of M-Banking, the following summary of respondents is discussed as follows. As can been seen in the table regarding their agreement on their use computer at their work, majority of respondents $41.3 \%$ agreed that, they use computer at their work. The researcher also directly posed a question regarding their use email communication with employees at their work. Based on this the Majority $62 \%$ of respondents disagreed that they use e-mail communication with employees at their work. With regard to a question they were asked whether they are using smart phone for their telephone communication, the majority of respondents $68.9 \%$ were agreed to the statement, As seen from the above table, majority $34.1 \%$ are neutral on the statement that they use smart phone applications to contact with family and friends outside the country Moreover, most of (51.7\%) respondents responded that they use online (WWW) resource to find any information relevant to them.

In order to find out demographic factors (voluntariness of use) affects adoption of MBanking, the following summary of respondents is discussed as follows with regard to "M-banking adoption increase social status of the user.," majority of respondents $44.8 \%$ were disagreed the statement. 
As seen from the above table, majority $37.9 \%$ also agreed that M-banking service users will be perceived well by others in the group. Most of respondents $41.4 \%$ also agreed that using M-banking service maintains their privacy and comfort. Moreover, most of respondents, $48.2 \%$ responded that using M-banking service save their time. From the above also, most of respondents $41.3 \%$ disagree that $\mathrm{M}$ banking provides $24 / 7$ banking service.

In order to find out respondents opinions about M-banking Adoption, the following summary of respondents is discussed as follows. As can been seen in the above table regarding their agreement on $\mathrm{M}$ banking adoption enhanced financial performance of the bank., majority of respondents $48.6 \%$ agreed to the statement. The researcher also directly posed a question regarding the Adoption of $\mathrm{m}$ banking System enables customers to accept their accounts information timely. Based on the question, the majority $(48.6 \%)$ of respondents agreed that Adoption of mbanking System enables customers to accept accounts information. With regard to question raised on whether the adoption of m-banking System improves the quality of banking service or not, the majority of respondents $62.1 \%$ were agreed with the statement. With regard to the question raised on adoption of m-banking System enables to continue accessing accounts 24/7, the majority of respondents $44.8 \%$ were agreed to the statement.

\section{Conclusions of the findings}

This section elaborates the major findings of the research in line with the research objectives. In conclusion, the researcher presents how the current research objectives have been realized in light of the previous elaborated discussion of results. The descriptive statistics results of the survey indicated that participants' of demographic characteristics in gender distribution revealed that the majority of the respondents from customer and employees perspective respectively were male 234(64\%), 131(65.5\%). In addition, the age of the respondents about (292)78.5\% from customer and (139) $69.5 \%$ from employee in this survey were between 20 years and 30 years. The findings also revealed that the majority of the respondent around $254(67.9 \%)$ from customer and 143(71.5\%) from employee are degree and above degree holders', This result supports the findings of a lot of studies on e-banking technology acceptance, where users tended to be young and had at least secondary school level of education (Amel, 1986; ElHaddan\&Almahmeed, 1992; Marshal \&Heslop, 1988; Swinyard\& Ghee, 1987; Taube, 1988).In addition, income distribution of the respondents revealed that about (162) $43.5 \%$ from customer and (111) $55.5 \%$ employee participants had monthly income $\geq 5,251$ Birr, which is considered average income in government organizations in Ethiopia. The profession composition of the respondent also revealed that about $276(74.2 \%)$ of the respondents are employed either in government or private institutions. From the aforementioned result it can be concluded that Unites Bank can use the young and educated customers as well as employees to its advantage of M-Banking adoptions by creating awareness about the technology. 
The result of Person's correlation test revealed that, there is significant positive and moderate relation between organizational factor and adoption of $\mathrm{m}$ banking $(\mathrm{r}=.531$, sig=.000), there is also significant, positive and moderate relation between Technological factor and adoption of m-banking ( $\mathrm{r}=.487$, sig=.000), there is also significant and moderate relation between customers' voluntariness of use and adoption of m-banking ( $\mathrm{r}=.531$, sig=.000) and there is significant but weak relationship between customer's experience and adoption of m-banking. ( $\mathrm{r}=.150$, sig= .000). However, there is no significant relation between Environmental factor and adoption of $\mathrm{m}$-banking. (sig. value $>.05=$ 0.227), there is no significant relationship between gender as demographic factor and adoption of $\mathrm{m}$-banking. (sig. value $>.05=$ .428 ), and also there is no significant relationship between age as demographic factor and adoption of m-banking. (sig. value>.05 $=.321$ ). The result of the regression analysis indicate that Organizational and Technological factors from the institution and customers' Experience and Voluntariness of use from the demographic factor together accounts for $31.6 \%$ of the variance on the intention to adopt m-banking technology. The results of the regression analysis indicate that Organizational and Technological factors from the institution and customers' Experience and voluntariness to use from Demographic factor together in United Bank accounts for $31.6 \%$ of the variance on the intention to adopt M-banking technology. The result of the regression analysis also revealed that Environmental factor from the institution and gender and age as demographic factors contributed null to the adoption of m-banking.

\section{References}

(n.d.). Retrieved from United Bank (Unitedbankscohttp://www.united bank.com.et).

(2017/18). NBE Annual Report.

Ackah David, Makafui R. Agboyi. (2014). Adoption of electronic banking in Ghana banking system, a case study of trhust bank (Ghana) limited,thesis, atlantic international university AIU, Hawaii, Honolulu, USA. Ghana.

Adams. D.A., N. R. (1992). Percived usefulness, ease of use and usage of information technology. A replication. MIS quarterly, 16(2), , 227-247.

(n.d.). $A D B(2013)$ Financial Inclusion in Africa. African Development Bank(2013) Tunisia.

Ajzen, I. (1991). The Theory of Planned Behavior, . "Organizational Behavior and Human Decision Process (50:2), 179-211.

Akintoye, A., McIntosh, G., \& Fitzgerald, E. (2000). A survey of supply chain collaboration and management in the UK construction industry. European journal of purchasing \& supply management, 159168.

Albaloushi, H., \& Skitmore, M. (2008). Supply chain management in the UAE. International Journal of Construction Management, 53-71.

Arntzen, B., Brown, G. G., Harrison, T. P., \& Trafton, L. L. (1995). Global supply chain management at Digital Equipment Corporation.

Ayana. (2012). Adaptaion of Electronic Banking System in Ethiopia Banking Industry:Barriers and Drivers MSc Thesis, AAu.

Bazhin, I. (2003). Logistics: CD tutorial. Kharkov: Kon-sum.

Boshoff, C. \&. (2009). Service Marketing: A Conteporary Approach. . Cape Town: Juta and Company Ltd. . 
Bubshait, A. .., \& Almohawis, S. .. (1994). Evaluating the general conditions of a construction. International Journal of Project Management 12 (3), 133-135.

Chen, I., \& Paulraj, A. (2004). Understanding Supply Chain Management: Critical Research and a theoretical framework. International Journal production and research 42(1), 131-163.

Choudhury, I., \& Rajan, S. (2003). Time-cost relationship for residential construction in Texas. 78.

Donlon, J. (1996). Maximizing value in the supply chain. Chief Executive, 117.

Dyer, J. H., \& Chu, W. (2003). The role of trustworthiness in reducing transaction costs \& improving performance, empirical evidence from United States, Japan, \& Korea. Organization Science, 14(1), 5768.

EBA, E. B. (2014). Supply Chain Finance EBA European market guide Version 2.0. Euro Banking Association.

Enshassi, A., Mohamed, S., \& Abushaban, a. S. (2009). Factors affecting the performance of construction projects in the Gaza strip. J. Civ. Eng. Manag.

Eshete, Z. S., \& Teshome, K. W. (2015). Performance, Challenges and Prospects of RealEstate Financing in Addis Ababa. American Journal of Economics, Finance and Managment, 1-9.

Ethiopian Economic Association, E. (2006/2007). The current state of the construction industry. Addis Ababa: Ethiopian Economic Association.

Gemeda, H. B. (2012). Effect Of Poor Project Performance On The Quality Of Housing Construction, Case of Condominium Houses In Addis Ababa. Rotterdam, The Netherlands (IHS): Institute for Housing and Urban Development Studies.

GTZ-IS, E. (2005). Low cost housing technical manual. Addis Ababa: Ministry of Federal Affairs.

Ishengoma, A. (2011). Analysis of Mobile Banking for finanicial Inclusion in Tnzania.
Johnston, D. A., Mccutcheon, D. D., Stuart, I. F., \& Kerwood, H. (2004). Effects of supplier trust on performance of cooperative supplier relationships. Journal of Operation Management, 22(1), 23-38.

KIMONDO1, J. M., \& WINJA, R. M. (2016). Influence of Supply Chain Management Systems on Construction. International Journal of Business \& Law Research, 1728.

Koskela, L., \& Vrijhoef, R. (1999). Roles of supply chain management in construction. California: California University.

Latham, M. (1994). Constructing the Team. London: HMSO.

Lim, C. .., \& Mohamed, M. .. (2000). An exploratory study into recurring construction problems. International Journal of Project Management 8, 267 273 .

M.Y., C. (2019). Overview of the Technology Acceptance Model:Origions Development and Future Directions, Indiana University. USA: Sprouts: Working Paper on Information System 9(37).

Mahamid, I., \& Bruland, A. (2012). Cost deviation in conmstruction projects. The case of Palestine. Australasian journal of construction economics and building, Vol.12.

Majid, I. (2006). Couses and effets of delay in Aceh construction industry. Johor Bahru, Malaysia.: Malaysia University of Technology.

McCormack, K., Johnson, W., \& Walker., W. T. (2003). Supply chain networks and business process orientation : advanced strategies and best practices. United States of America: CRC Press LLC.

Mentzer, J., T.Min, \& Zacharia, S. (2000). The nature of interfirm partnering in supply chain management. Journal of Retailing, Vol. 76, No. 4, pp.549-568.

Min, S., \& Mentzer, J. (2004). Developing and measuring supply chain concepts. Journal of Business Logistics; 25(1), 63-99. 
Moharana, P. H., Murty, D. J., Senapati, D. S., \& Khuntia, P. K. (2006). Importance Of Information Technology For Effective Supply Chain Management. International Journal of Modern Engineering Research (IJMER) Vol.1, Issue.2, pp-747-751.

MoWUD, M. o. (2006). Urban development policy. Addis Ababa.

National Bank of Ethiopia (NBE, http://www.nbe.gov.et/aboutus/index.html) . (n.d.).

Octavio, B. T. ( August 2007). An investigation of green supply chain management in the. Norwich: University of East Anglia.

Prasad, A. a. (1997). the role of Innovation Characterstics and perceived voluntariness in the acceptance of information technologies. Decisio Science (28:3), 557582.

Rose, K. .. (1995). A performance measurement model; Quality Progress. 63 - 66 .

Sohai, A.-J. \&. (2012). Jornal of Electronic Commerce Research, Vol 13, No 4,.

(n.d.). Spotts, T.H. (1999). Discriminating factors in faculty use of instructional technology in higher education.Educational Technology \& Society, 2(4), 92-99.

Swinyard, W. R. \& Ghee, L. (1987). Adoption patterns of new banking technology in Southeast Asia. International Journal of Bank Marketing, 5(4), 35-48. . (n.d.).

Tan, K., Kannan, V., \& Handfield, R. (1998). Supply chain management: supplier performance and firm performance. Tan KC, Kannan VR, Handfield RB(1998). Supply chain management:International Journal of Purchasing and Materials Management.

Technologies On Customer Behavior And Its Implications For Banks www.tuharburg.de/tim accessed on February, 2019 . (n.d.).

Tesfa, S. Y. (2015). Analysis of Factors Contributing to Time Overruns on Road Construction Projects under Addis Ababa City Administration. ADDIS ABABA University, Ethiopia: Department of
Management, College of Business and Economics.

Tiwari Et Al (2006). Mobile Banking As Business Strategy: Impact Of Mobile Technologies On Customer Behavior And Its Implications For Banks . (n.d.).

(n.d.). United bank annual report 2018.

V. Charles Durai, D. K. (2016). A Study On Supply Chain Frame Work In Construction Industry. International Journal of Research, 16-26.

Venkatesh, V. M. (2003). User Acceptance of Information Technology: Toward a Unified View. . MIS Quarterly. 27(3),, 425-478.

Wezop, D. v. (2016). Supply chain integration in the construction industry. Open University of the Netherlands.

Xue, X., Li, X., Shen, Q., \& Wang, Y. (2005). An agent-based framework for supply chain coordination in construction. In Automation in Construction (pp. 413-430).

Yu, C.-S. (2012). Factors Affecting Indviduals to Adopt Mobile Banking: Empirical evidence from the UTAUT model . 